\title{
Myiasis pada Ruminansia: Diagnosis, Manajemen Terapi dan Pencegahan
}

\author{
Myiasis in ruminants: Diagnosis, Therapy and Prevention Management
}

\author{
Yanuartono, Soedarmanto Indarjulianto*, Alfarisa Nururrozi dan Hary Purnamaningsih \\ Laboratorium Ilmu Penyakit Dalam, Fakultas Kedokteran Hewan, Universitas Gadjah Mada \\ Jl. Fauna No. 2. Catur Tunggal, Sleman Yogyakarta Indonesia (55281)
}

\author{
Article history \\ Accepted: October 7, 2019 ; \\ Approved: July 17, 2019 \\ * Corresponding author: \\ E-mail: \\ indarjulianto@ugm.ac.id
}

\begin{abstract}
Myiasis is defined as a condition in which maggots are from certain fly species that utilize living, dead, or necrotic tissue from the host as a feed source for their growth and development and attack all types of vertebrate animals that are warm-blooded including humans. Myiasis is often found in domestic animals in tropical regions throughout the world, especially in developing countries such as Indonesia and is generally associated with low levels of welfare of farmers. The diagnosis of myiasis is based on a clinical examination of wound bleeding, fever, a characteristic odor, the discovery of exudates and maggots in the wound. Myiasis treatment is generally local followed by manual removal of larvae and necrotic tissue debris. Systemic treatment usually uses broad-spectrum antibiotics especially when secondary infections occur. Disease prevention can be done by providing information to farmers to pay attention to and carry out livestock sanitation, pens, the surrounding environment and control flies using various methods. However, the various methods have varying degrees of success, thus the choice of method must be made with careful consideration. Conclusion: myiasis is a disease caused by ectoparasites that affects to the condition of livestock. The main predisposition of myiasis is the low level of animal hygiene, cage and environment. Besides the chemical drugs that have been used now, it is necessary to develop traditional medicines that are easily obtained and made using local ingredients. Aside from treatment, various fly control methods have been developed, although the success rate is still very varied.
\end{abstract}

Keywords: clinical examination, disease prevention, maggot, myiasis

\section{Pendahuluan}

Myiasis didefinisikan sebagai kondisi maggot atau belatung yang berasal dari spesies lalat tertentu yang memanfaatkan jaringan yang hidup, mati, atau nekrosis dari hospes sebagai sumber pakan untuk pertumbuhan dan perkembangannya (Rahman et al., 2009; Imtiaz et al., 2014). Menurut Rohela et al. (2006) myiasis menyerang semua jenis hewan vertebrata yang berdarah panas termasuk manusia. Di Indonesia, meskipun belum banyak terdokumentasi, larva lalat $C$. bezziana diduga banyak mengakibatkan myiasis pada ternak lokal yang dipelihara secara intensif di pulau Jawa, Madura dan Bali. Sebaliknya, ternak lokal yang dipelihara secara semiekstensif atau secara ekstensif di daerah Nusa Tenggara Barat, Nusa Tenggara Timur, Sulawesi Selatan, dan Sulawesi Utara telah banyak dilaporkan (Wardhana dan Muharsini, 2005). Menurut Badan Kesehatan Hewaan Dunia atau Office International des Epizooties (OIE, 2013), myiasis termasuk dalam kategori penyakit menular yang mempunyai dampak sosial ekonomi atau kesehatan di dalam suatu negara, serta berdampak nyata dalam perdagangan internasional terkait dengan produk-produk asal hewan.

Menurut Kaufman et al., (2006), myiasis diawali dengan adanya kelukaan pada tubuh hewan ternak. Kelukaan tersebut dapat disebabkan oleh berbagai macam faktor seperti 
gigitan serangga, operasi kastrasi, abses, kawat atau logam dan perkelahian antar ternak sehingga menjadi tempat untuk infestasi larva (Moyo dan Masika, 2009). Rendahnya tingkat kebersihan hewan, kandang, sehingga mengakibatkan pencemaran lingkungan sekitar dan mengundang lalat merupakan faktor predisposisi utama kejadian myiasis (Fathurrohman et al., 2015). Myiasis dapat mengakibatkan turunnya produksi susu, berat badan, kualitas kulit, wol, abortus dan gangguan sistem pertahanan tubuh hospes (Otranto dan Stevens, 2002). Kejadian myiasis pada ternak peliharaan telah banyak dilaporkan pada sapi (Umadevi dan Umakanthan, 2016), domba (Dehghani et al., 2014), kambing (Juyena et al., 2013), kuda (Traversa dan Otranto, 2006), dan babi (Kamble et al., 2016). Hewan penderita myiasis biasanya menunjukkan gejala kelemahan umum, anemia dan pada kasus yang tidak ditangani dapat mengakibatkan toksemia yang berujung pada kematian (Schnur et al., 2009).

Pengobatan myiasis meliputi pencucian luka, pengambilan belatung dan pemberian antibiotika lokal dan sistemik (Jesse et al., 2016). Namun sampai saat ini obat yang paling sering digunakan untuk kejadian myiasis adalah insektisida seperti asuntol, ivermectin dan rotenone (Dourmishev et al., 2005). Saat ini telah banyak dicoba penggunaan obat tradisional untuk mengobati myiasis karena semakin mahal serta sulitnya memperoleh obat obatan terutama di daerah pedesaan yang terpencil. Pengendalian harus difokuskan pada perbaikan manajemen pemeliharaan karena merupakan cara paling tepat dalam menurunkan kejadian myiasis pada hewan ternak. Tindakan menurunkan atau bahkan menghilangkan faktor-faktor risiko seperti munculnya abses, penanganan pasca melahirkan, infeksi pusar, kontaminasi feses dan urin perlu dilakukan secermat mungkin untuk menekan kejadian myiasis.

\section{Penyebab Myiasis}

Menurut OIE (2013) mengklasifikasikan lalat penyebab myiasis menjadi New World screwworm fly (NWS) Cochliomyia hominivorax dan Old World screwworm (OWS). Contoh NWS adalah Cochliomyia hominivorax, sedangkan OWS adalah Chrysomya bezziana dan saat stadium larva keduanya merupakan parasit obligat pada mamalia. Klasifikasi myiasis dapat dilakukan dengan 2 cara yang berbeda. Klasifikasi pertama adalah berdasarkan lokasi terdampak seperti kulit, nasofaring, okular, saluran pencernaan dan urogenital (Goddard, 1996), sedangkan klasifikasi kedua didasarkan atas hubungan hospes dengan parasit seperti obligat, fakultatif dan insidental (Yones et al., 2014). Menurut Gealh et al. (2009) penyebab primer myiasis dapat dikelompokkan menjadi 3 yaitu : (1) lalat Cochliomya hominivorax yang banyak terdapat di benua Amerika, (2) Wohlfahrtia magnifica yang tersebar di Eropa hingga Cina daratan dan (3) Chrysomya bezziana yang tersebar di Afrika, India dan Asia Tenggara termasuk Indonesia serta Papua New Guinea. Menurut Hall dan Wall (1995), pada awalnya lalat tertarik pada luka terbuka, cairan berbau busuk atau bahkan luka sekecil ukuran gigitan kutu cukup untuk menarik lalat meletakkan telurnya. Faktor-faktor predisposisi kejadian myiasis pada ternak adalah infeksi umbilikus pada pedet rendahnya tingkat kebersihan bedding dan kandang, kontaminasi bulu, feses, urin dan adanya luka di kulit (Patra et al., 2012). Tabel 1. menunjukkan penyebab dan lokasi myiasis pada hewan ternak dan manusia di berbagai negara.

Kejadian myiasis pada kulit paling sering dijumpai pada ternak dengan manifestasi klinis berupa furunkula, migrasi dan traumatika (Francesconi dan Lupi, 2012). Secara umum, jenis lalat yang menyebabkan myiasis termasuk dalam famili Calliphoridae (Stevens, 2003), Sarcophagidae (Giangaspero et al., 2017), Hypodermatidae (Pavlásek dan Mináŕ, 2014), Oestridae (Zanzani et al., 2016) dan Gasterophilidae (Huang et al., 2016). Sedangkan jenis lalat yang menyebabkan myiasis furunkula adalah Dermatobia hominis (Meurer et al., 2016), Cordylobia anthropophaga (Fujisaki et al., 2008), Wohlfahrtia vigil (Dehghani et al., 2014), dan spesies Cuterebra (Crumley et al., 2011). Myiasis migrasi disebabkan oleh jenis lalat Gasterophilus (Miguélez et al., 2016), dan Hypoderma (Otranto et al., 2016). Sedangkan lalat yang menyebabkan myiasis traumatika 
adalah Cochliomyia hominivorax (CalderonCastrat et al., 2017), Chrysomya bezziana
(Sukarsih, et al., 1989) dan Wohlfahrtia magnifica (Kheirabadi et al., 2014).

Tabel 1. Penyebab dan lokasi myiasis pada hewan ternak dan manusia

\begin{tabular}{|c|c|c|c|c|}
\hline Penyebab & Lokasi terdampak & Hewan & Negara & Pustaka \\
\hline W. magnifica & Telinga & Anjing & Turki & Dik et al. (2012) \\
\hline L. sericata & Perianal & Kucing & Turki & Dik et al. (2012) \\
\hline H. ligurriens & Kepala & Kambing & India & Sinha (2012) \\
\hline L. sericata & Pantat & Anjing & Korea & Choe et al. (2016) \\
\hline $\begin{array}{c}\text { C. } \\
\text { anthropophaga }\end{array}$ & Luka seluruh tubuh & Anjing & Nigerian & Chukwu et al. (2012) \\
\hline Dipteria, sp. & Mulut & Manusia & India & Guledgud et al. (2014) \\
\hline C. rodhaini & Kepala & Manusia & Ethiopia & Tolera (2017) \\
\hline P. terraenovae & Vagina & Manusia & Kanada & Predy et al. (2014) \\
\hline C. bezziana & Vulva & Sapi & Bangladesh & Islam et al. (2015) \\
\hline $\begin{array}{l}\text { C. bezziana dan } \\
\text { Lucilia sp. }\end{array}$ & Telinga, mata, kepala & Antelope & Kenya & Obdana et al. (2013) \\
\hline W. magnifica & Perinel, vagina & Unta & Iran & Kheirabadi et al. (2014) \\
\hline C. bezziana & $\begin{array}{c}\text { Perianal, pangkal } \\
\text { ekor, leher dan kuku }\end{array}$ & $\begin{array}{l}\text { Sapi, } \\
\text { kerbau }\end{array}$ & India & Singh dan Singh (2016) \\
\hline L. sericata & Sekitar anus & Kelinci & Inggris & Cousquer (2006) \\
\hline C.hominivorax & $\begin{array}{l}\text { Mdanibula dan } \\
\text { buccae }\end{array}$ & Serigala & Brasil & Cansi et al. (2011) \\
\hline $\begin{array}{c}\text { Musca } \\
\text { domestica }\end{array}$ & $\begin{array}{l}\text { Pertengahan tubuh } \\
\text { ular }\end{array}$ & $\begin{array}{c}\text { Ular } \\
\text { Pseudocer } \\
\text { astes } \\
\text { persicus }\end{array}$ & Iran & Dehghani et al. (2012) \\
\hline
\end{tabular}

Jenis lalat yang sering menyebabkan kejadian myiasis pada ternak di negara tropis adalah Chrysomya bezziana yang merupakan parasit obligat pada hewan berdarah panas (Katoch et al., 2014). Kejadian myiasis akibat lalat Chrysomya bezziana telah banyak dilaporkan di berbagai negara seperti Indonesia (Wardhana dan Muharsini, 2005), Saudi Arabia (Alahmed, 2004), Irak (AlTaweel et al., 2000), Iran (Ready et al., 2009), Sri Lanka (Prasad et al., 2000), India
(Katoch et al., 2014), Malaysia (Jesse et al., 2016), Brazil (Ribeiro et al., 2003), Amerika Serikat (Alexdaner, 2006), Afrika Selatan (Soyelu dan Masika, 2009) dan Australia (Beckett et al., 2014). Menurut Rajamanickam et al., (1986) prevalensi myiasis pada sapi yang disebabkan larva lalat C. bezziana di Malaysia mencapai $84 \%$ dan 95\%. Terjadinya peningkatan kejadian penyakit kasus myiasis pada 80 ekor Persian fallow deer (Dama dama mesopotamica) 
yang disebabkan Chrysomya bezziana di Iran menunjukkan 40 ekor mengalami kematian. Hewan tersebut itu sebagian besar mengalami luka kulit traumatis pada bagian telinga, mata, kepala dan juga leher bagian ventral (Mombeni et al., 2014). Kejadian dan derajat keparahan myiasis tergantung pada kondisi daerah tersebut seperti distribusi, kepadatan ternak dan kondisi iklim. Populasi lalat sangat bervariasi sepanjang tahun dan biasanya paling melimpah saat musim panas serta lembab seperti di Australia dan negara negara Timur Tengah (Tabouret et al., 2001; Otranto et al., 2006). Sedangkan di Indonesia, populasi lalat akan meningkat pada saat menjelang dan selama musim hujan (Wardhana dan Muharsini, 2005)

\section{Diagnosa dan Gejala Klinis Myiasis}

Ketelitian dan kecermatan peternak dalam mengamati hewannya sangat dibutuhkan untuk mengenali gejala klinis yang muncul sedini mungkin karena merupakan kunci untuk ketepatan mendiagnosa myiasis. Identifikasi kasus biasanya didahului dengan keterangan keluhan pemilik, riwayat penyakit, kondisi hewan secara umum seperti sikap hewan, kondisi tubuh body condition score (BCS), cara berdiri maupun berjalan dan kemungkinan luka yang tampak dari jauh (Radostits et al., 2000). Diagnosis selanjutnya dibuat berdasarkan pemeriksaan klinis adanya perdarahan luka, demam, bau khas, ditemukannya eksudat dan belatung pada luka (Blood dan Henderson, 1983). Menurut Negm-Eldin et al., (2015) kejadian myiasis pada rongga hidung serta sinus domba dan kambing yang disebabkan oleh Oestrus ovis. Gejala klinis yang ditemukan berupa sinusitis, rhinitis, eksudat purulen, kesulitan bernafas, pernapasan melalui mulut, kekurusan dan dapat menyebabkan kematian.

Hasil penelitian serta laporan kasus menunjukkan bahwa bagian tubuh yang rawan mengalami kelukaan pada sapi dan kambing adalah vagina (Sinha, 2012), skrotum (Dehghani et al., 2014), perineal (Kheirabadi et al., 2014), interdigiti (Singh dan Singh, 2016), kaki depan bagian atas, inguinal (Duro et al., 2007), paha, ambing, kepala (Amin et al., 1997), pangkal tanduk (Ribeiro et al., 2002), hidung (Dorchies et al.,
2000), telinga dan leher (Imtiaz et al., 2014). Gejala klinis yang muncul akibat myiasis pada berbagai hewan disajikan pada Tabel 2 .

Pada Tabel 2 terlihat bahwa lokasi luka kulit dapat ditemukan di hampir seluruh tubuh, terutama di daerah vagina, perineal, pusar, leher, kepala dan kuku. Menurut Islam et al. (2015) manifestasi klinis dan patologis myiasis pada hewan bergantung pada genus dan spesies lalat, model invasi larva, derajat dan tipe migrasi setelah invasi serta tahap siklus hidupnya. Meskipun demikian, diagnosis pasti kasus myiasis ditentukan dengan ditemukannya belatung pada daerah luka.

\section{Terapi dan Kontrol Myiasis}

Penanganan myiasis pada umumnya berupa pengobatan bersifat lokal dan sistemik (Bhagawati et al., 2013). Pengobatan lokal ditekankan pada aplikasi topikal menggunakan minyak terpentin, minyak mineral, kloroform, etil klorida, atau merkuri klorida diikuti dengan pengambilan secara manual larva dan runtuhan jaringan yang mengalami nekrosis (Francesconi dan Lupi, 2006). Perawatan sistemik termasuk antibiotik spektrum luas seperti ampisilin dan amoksisilin terutama ketika terjadinya infeksi sekunder (Sankari dan Ramakrishnan, 2010). Perawatan luka yang tepat merupakan syarat mutlak untuk memperoleh prognosa yang baik. Manajemen perawatan luka yang tepat sangat penting untuk mencapai prognosis yang baik.

Saat ini telah dikembangkan obat obatan herbal tradisional untuk terapi myiasis. Pengalaman tim penulis di lapangan juga menunjukkan bahwa peternak sapi di Daerah Istimewa Yogyakarta (DIY) yang berada di pelosok pedesaan hampir semua menggunakan air tembakau untuk mengeluarkan larva yang terdapat dalam luka (data tidak dipublikasikan). Hasil survei Soyelu dan Masika (2009) pada peternak sapi di Afrika selatan, terapi myiasis menggunakan tanaman Aloe ferox Mill, Prunus persica (L.) Batsch dan Phytolacca heptdanra Retz yang dibuat menjadi bentuk infusa dan diberikan secara topikal. Hasil penelitian Widhyari et al. (2018) menunjukkan bahwa domba garut penderita 
myiasis dapat sembuh dengan pemberian salep ekstrak daun sirih merah (Piper crocatum) $2 \%$ dan $4 \%$. Penelitian in vitro untuk pengobatan myiasis menunjukkan bahwa ekstrak ethanol daun binahong (Danredera cordifolia Steenis) memiliki kemampuan menghambat pertumbuhan larva lalat C. bezziana (Wientarsih et al., 2017). Sedangkan Astuti et al. (2017) berhasil menggunakan krim ekstrak biji bengkuang (Pachyrhizus erosus) yang mengdanung bahan aktif rotenon $0.5-1.0 \%$ untuk pengobatan myiasis.

Tabel 2. Gejala klinis myiasis pada hewan

\begin{tabular}{|c|c|c|c|}
\hline Hewan & Lokasi luka & Gejala klinis & Pustaka \\
\hline $\begin{array}{l}\text { Rusa Persia (Dama } \\
\text { dama } \\
\text { mesopotamica) }\end{array}$ & $\begin{array}{l}\text { Telinga, mata, } \\
\text { kepala dan leher } \\
\text { bagian bawah }\end{array}$ & $\begin{array}{l}\text { Stress, terdapat belatung dalam lesi, } \\
\text { menggigit dan menggosokan daerah } \\
\text { luka }\end{array}$ & Mombeni et al., 2014 \\
\hline $\begin{array}{l}\text { Pedet silangan } \\
\text { Brangus }\end{array}$ & $\begin{array}{l}\text { Perineum, vulva } \\
\text { dan anus }\end{array}$ & $\begin{array}{l}\text { Nekrosis daerah vulva dan anus, } \\
\text { ditemukan belatung pada daerah lesi }\end{array}$ & Jesse et al., 2016 \\
\hline $\begin{array}{l}\text { Eldan } \\
\text { (Taurotragus } \\
\text { derbianus) }\end{array}$ & $\begin{array}{l}\text { Telinga, mata dan } \\
\text { kepala }\end{array}$ & $\begin{array}{l}\text { Perdarahan di telinga, mata dan } \\
\text { kepala, sering menggelengkan } \\
\text { kepala, menggerakan telinga, } \\
\text { berjalan sempoyongan dan } \\
\text { gangguan penglihatan }\end{array}$ & Obdana et al., 2013 \\
\hline Kerbau & Ekor & Luka terbuka pada pangkal ekor & Katoch et al., 2014 \\
\hline Sapi & $\begin{array}{l}\text { Pusar, vulva, } \\
\text { paha, ambing, } \\
\text { bahu dan kuku }\end{array}$ & $\begin{array}{l}\text { Kelukaan di pusar, vulva, paha, } \\
\text { ambing, bahu,kuku, eksudat daerah } \\
\text { luka dan ditemukannya belatung }\end{array}$ & Rahman et al., 2009 \\
\hline Sapi FH & $\begin{array}{l}\text { Vagina, } \\
\text { ekor, } \\
\text { kukusar, } \\
\text { telingala, } \\
\text { luar, dan mulut }\end{array}$ & $\begin{array}{l}\text { Kelemahan umum, demam, stress, } \\
\text { ditemukan belatung pada daerah } \\
\text { kelukaan }\end{array}$ & Imtiaz et al., 2014 \\
\hline Sapi perah & $\begin{array}{lr}\text { Vulva, } & \text { kuku, } \\
\text { pangkal } & \text { tdanuk, } \\
\text { leher, } & \text { pangkal } \\
\text { ekor dan perianal }\end{array}$ & $\begin{array}{l}\text { ditemukannya belatung pada daerah } \\
\text { kelukaan }\end{array}$ & Singh dan Singh, 2016 \\
\hline Domba & Mata & $\begin{array}{l}\text { Mata gatal, lakrimasi, kemerahan, } \\
\text { nyeri, bengkak, kemosis, dan } \\
\text { ditemukannya benda asing }\end{array}$ & $\begin{array}{l}\text { Sucilathangam et al., } \\
2013\end{array}$ \\
\hline
\end{tabular}

Pencegahan merupakan tindakan yang paling tepat dilakukanan untuk meminimalkan risiko kejadian myiasis. Pencegahan penyakit dapat dilakukan dengan memberikan penyuluhan kepada para peternak untuk memperhatikan dan menjalankan secara seksama sanitasi ternak, kandang, lingkungan sekitar dan pengawasan lalu lintas ternak antar daerah (Nururrozi, et al., 2017). Tindakan lain untuk mendukung pencegahan kejadian myiasis adalah melalui pengendalian lalat penyebab miasis. Berbagai bentuk pengendalian telah dikembangkan yaitu antara lain dengan penggunaan insektisida atau pestisida (Ahmad et al., 2012), minyak esensial (Chaaban et al., 2017), vaksin 
rekombinan (Sukarsih et al., 2000), pembuatan perangkap dan pemikat lalat (Tang et al., 2016) dan metode Sterile Insect Technique atau SIT (Horner et al., 2016).

\section{Kesimpulan}

Myiasis merupakan salah satu penyakit yang disebabkan oleh ektoparasit yang mempengaruhi kondisi ternak secara keseluruhan. Predisposisi utama kejadian myiasis adalah rendahnya tingkat kebersihan hewan, kandang dan lingkungaan sekitar. Disamping obat yang telah digunakan saat ini maka perlu dikembangkan obat tradisional yang mudah diperoleh dan dibuat dengan memanfaatkan bahan bahan lokal. Selain pengobatan, saat ini telah dikembangkan berbagai metode pengendalian lalat meskipun tingkat keberhasilannya masih sangat bervariasi.

\section{Daftar Pustaka}

Ahmad, H., How, T.T., Chi, T.C., Dieng, H., Sungit, S. H., dan Musa, S. 2012. The efficacy of insecticides (Fendona dan Malathion) against larvae dan adult stages of Musca domestica. The Proceedings of The 2nd Annual International Conference Syiah Kuala University 2012 \& The 8th IMT-GT Uninet Biosciences Conference Banda Aceh (pp. 91-95).

Alahmed, A. M. 2004. Myiasis in sheep farms in Riyadh Region, Saudi Arabia. J Egypt Soc Parasitol. 34(1), 153-160.

Alexdaner, J. L. 2006. Screwworms. JAVMA, 228 (3), 357-367.

Al-Taweel, A.A., Al-Izzi, M.A.J., dan Jassim, F.A. 2000. Incidence of Old World screwworm fly, Chrysomya bezziana , in Iraq . Area-wide Control of Fruit Flies dan Other Insect Pests). Penerbit Universiti Sains Malaysia, Penang.

Amin, A.R, Shoukry, A., Morsy, T. A., dan Mazyad, S. A. M. 1997. Studies of wound myiasis among sheep dan goats in North Sinai Governorate, Egypt. J Egyp Soc Parasitol. 27(3), 719-737.

Astuti, R., Rivaldi, Y., Sakinah, N. A., Nafilah, A. Z., dan Putra, S. S. 2017. Creamy: krim ekstrak biji bengkuang (Pachyrhizus erosus) sebagai alternatif obat antimyiasis yang aman, efektif, dan ekonomis. Asian J Innov Entrepreneur, 02 (03), 315-320.

Beckett, S.D., Spradbery, J.P., Green, P.E., Urech, R., dan James, P. 2014. Old World Screw-Worm Fly: Risk of entry into Australia dan surveillance requirements. $A$ report for Animal Health Australia, Canberra (November, 2014).

Bhagawati, B. T., Gupta, M. dan Singh, S. 2013. Oral myiasis: a rare entity. Europ $J$ Gen Dentist, 2 (3), 312-314.

Blood, D.C., dan Henderson. 1983. Veterinary Medicine. 6th edn., Bailliere Tindal. 1st Anne's Road, Eastbourne, East Sussex BB 213 UN. pp. 807-808.

Calderon-Castrat, X., Idrogo-Bustamante, J. L., Peceros-Escalante, J., dan Ballona, R. 2017. Wound myiasis caused by Cochliomyia hominivorax: the role of entodermoscopy. Int J Dermatol. 56(3), 330-332.

Chaaban, A., Gomes, E.N., Santos, V. M.C.S., Deschamps, C., dan Molento, M. B. 2017. Essential oils for myiasis control: potentialities for ecofriendly insecticides. Europ J Med Plants. 21(4), 1-25.

Crumley, W. R., Rankin, A. J., dan Dryden, M. W. 2011. Ophthalmomyiasis Externa in a Puppy due to Cuterebra Infestation. $J$ Americ Anim Hosp Assoc, 47(6), e150e155.

Dehghani, R., Zarghi, I., dan Sayyedi, H. R. 2014. Genital myiasis of a sheep by Wohlfahrtia magnifica, in Ghamsar, Kashan, Iran Bangladesh. J Med Sci, 13(03), 332-335.

Dorchies, P., Bergeaud, J.P., Tabouret, G., Duranton, C., Prevot, F., dan Jacquiet, P. 2000. Prevalence dan larval burden of $O$. ovis (Linne 1761) in sheep dan goats in northern Mediterranean region of France. Vet Parasitol. 88 (3-4), 269-273.

Dourmishev, A.L., Dourmishev, L.A, dan Schwartz, R.A. 2005. Pharmacology dan therapeutic. Ivermectin: pharmacology dan application in dermatology. Int. J. of Dermatol. 44 (12), 981-988.

Duro, E.A., Mariluis, J.C., dan Mulieri, P.R. 2007. Umbilical myiasis in a human newborn. J. Perinatol, 27(4), 250-251.

Fathurrohman, A., Hari, M. A., Zukhriyah, S. A., dan Adam, M. A. 2015. Persepsi 
peternak sapi dalam pemanfaatan kotoran sapi menjadi bio-gas di Desa Sekarmojo Purwosari Pasuruan. Jurnal Ilmu-Ilmu Peternakan, 25 (2), 36-42.

Francesconi, F., dan Lupi, O. 2012. Myiasis. Clin Microbiol Rev. 25(1), 79-105.

Francesconi, F., dan Lupi, O. 2006. Myiasis. In Tyring. S.K., Lupi O., Hengge U.R. (ed.), Tropical dermatology. Elsevier, Philadelphia, PA210.

Fujisaki, R., Makimura, K., Hayashi, T., Yamamura, M., Yamaoka, T., Shiraishi, K., Ishibashi, S., Kawakami, S., Kurihara, T., dan Nishiya, H. 2008. Exotic myiasis caused by 19 larvae of Cordylobia anthropophaga in Namibia dan identified using molecular methods in Japan. Trop Med Hygiene, 102(6), 599-601.

Gealh, W.C., Ferreira, G.M., Farah, J G., Teodoro, U., dan Camarini, E.T. 2009. Treatment of oral myiasis caused by Cochliomyia hominivorax, two cases treated with ivermectin. British $J$ Oral Maxillofac Surg. 47(1), 23-26.

Giangaspero, A., Marangi, M., Balotta, A., Venturelli, C., Szpila, K., dan Di Palma, A. 2017. Wound myiasis caused by Sarcophaga (Liopygia) Argyrostoma (Robineau-Desvoidy) (Diptera: Sarcophagidae): Additional evidences of the morphological identification dilemma dan molecular investigation. Scie World J. 1(1), 1-9.

Goddard, J. 1996. Flies whose maggots cause myiasis in humans. In: Physician's guide to arthropods of medical importance, 2nd edn. Florida: CRC Press, 1996.

Hall, M., dan Wall, R. 1995. Myiasis in humans dan domestic animals. $A d v$ Parasitol, 35, 257-312.

Huang, H., Zhang, B., Chu, H., Zhang, D., dan Li, K. 2016. Gasterophilus (Diptera, Gasterophilidae) infestation of equids in the Kalamaili Nature Reserve, China. Parasite, 23 (36), 1-4.

Imtiaz, M.A., Rahman, M.A., Islam, K., Barua, M., Alim, M.A., Chowdhury, S., dan Sikder, S. 2014. Prevalence dan associated risk factors of myiasis in different areas of Chittagong, Bangladesh. Res. j. vet. pract., 2 (2), 22-27.
Jesse, F. F. A., Sadiq, M. A., Abba, Y., Mohammed, K., Harith, A., Chung, E. L. T., Bitrus, A. A., Lila, M. A. M., Haron, A. W., dan Saharee, A. A. 2016. Clinical management of severe cutaneous myiasis in a brangus-cross calf. Int J Livestock Res. $6(6), 82-89$.

Juyena, N. S., Tapon, M. A. H., Ferdousy, R. N., Paul, S., dan Alam, M. M. 2013. A retrospective study on occurrence of myiasis in ruminants. Progress. Agric. 24(1\&2), 101-106.

Kamble, S., Ganguly, S., Qadri, K., dan Mahajan, T. 2016. Management of Auricular Myiasis in Swine: A Case Report. Int J Contemp Pathol 2 (1), 49-50.

Katoch, R., Godara, R., Yadav, A., Sharma, S., dan Ahmad, I. 2014. Occurrence of Chrysomya bezziana in a buffalo in Jammu. J Parasit Dis., 38(4), 420-422.

Kaufman, P.E., Koehler, P.G., dan Butler, J.F. 2006. External parasites on beef cattle. Entomology dan Nematology Department document, ENY-274. University of Florida, Gainesville, FL 32611. http://edis.ifas.ufl.edu/pdffiles/IG/IG13000 .pdf

Kheirabadi, K.P., Samani, A. D., dan Vardanjani, H. R. 2014. A report on the genital myiasis by Wohlfahrtia magnifica in camel herds in southwest of Iran. Vet Res Forum. 5 (4), 329-332.

Meurer, M.I., Grdano, L.J., Rivero, E.R.C., Souza, C.E.C.P., dan Marcondes, C.B. 2016. A rare case of labial myiasis caused by Dermatobia hominis. J Contemp Dent Pract., 17(11), 958-961.

Miguélez, S., Araújo, A. M., Francisco, I., Suarez, J., Sánchez-Danrade, R., Paz-Silva, A., dan Arias, M.S. 2016. Exposure to Gasterophilus spp. in horses in NW Spain by ELISA. J Entomol Zool Stud. 4(5), 621-624.

Mombeni, E.G., Mombeini, M.G., Lahijanzadeh, A., Kenarkohi, M., Mola, S.A., Hosseini, S. K., Rezaei, A. A., Garavdan, M. M., dan Khalaj, M. 2014. Management dan control of an outbreak of fatal truamatic myiasis due to Chrysomya bezziana in a herd of Persian Fallow Deer 
(Dama dama mesopotamica). J Vet Sci Technol., 5 (1), 1-4.

Moyo, B., dan Masika, P.J. 2009. Tick control methods used by resource-limited farmers dan the effect of ticks on cattle in the rural areas of the Eastern Cape Province, South Africa. Tropical Animal Health dan Production. 41(4), 517-523.

Negm-Eldin, M.M., Elmadawy, R.S., dan Hanan, G.M. 2015. Oestrus ovis larval infestation among sheep dan goats of Green Mountain areas in Libya. J. $A d v$. Vet. Anim. Res., 2(4), 382-387.

Nururrozi, A., Fitrdana, M., Indarjulianto, S., dan Yanuartono. 2017. Bovine Ephemeral Fever pada ternak sapi potong di Kabupaten Gunungkidul, Yogyakarta (Case Report). J Ilmu-Ilmu Peternakan. 27 (1), 101-106.

Office International des Epizooties (OIE). 2013. Screwworm (Old World dan New World). Technical Disease Card. www.oie.int.https://www.aphis.usda.gov/a nimal_health/...

/nws_myiasis_disease_strategy.pdf

Otranto, D., Johnson, G., Syvrud, K., Yoon, S., Hunter III, J.S., dan Rehbein, S. 2016. Treatment dan control of bovine hypodermosis with ivermectin long-acting injection (IVOMEC $®$ GOLD). Parasites \& Vectors. 9 (1),1-6.

Otranto, D., Stevens, J. R., Brianti, E., dan Dorchies, P. 2006. Human dan livestock migrations: a history of bot fly biodiversity in the Mediterranean region. Trends in Parasitol. 22 (5), 209-213.

Patra, S., Purkait, R., Basu, R., Konar, M. C., dan Sarkar, D. 2012. Umbilical myiasis associated with Staphylococcus aureus sepsis in a neonate. J Clin Neonatol. 1(1), 42-43.

Pavlásek, I., dan Minář, J. 2014. New host dan the extend of the host range of warble fly Hypoderma diana (Diptera, Hypodermatidae). Acta Mus. Siles. Sci. Natur., 63(1), 61-64. DOI: 10.2478/cszma2014-0008

Prasad, S., Kumarasinghe, W., Karunaweera, N.D., dan Ihalamulla, R. L. 2000. A study of cutaneous myiasis in Sri Lanka. Int $J$ Dermatol., 39(9), 689-694.
Radostits, O.M., Gay, C.C., Blood, D.C., dan Hinchcliff, K.W. 2000. Clinical examination and making a diagnosis. In: Veterinary Medicine, A textbook of the diseases of cattle, sheep, pigs, goats dan horses. 9th edn. W B Saunders. 3-40.

Rahman, M. A., Hossain, M. A., dan Alam, M. R. 2009. Clinical evaluation of different treatment regimes for management of myiasis in cattle. Bangl. $J$. Vet. Med. 7(2), 348-352.

Rajamanickam, C., Soon, C.T., dan Paramasvaran, S. 1986. The prevalence of myiasis of domestic animals in peninsular Malaysia. Kajian Veterinarian. 18, 153157.

Ready, P.D., Testa, J.M., Wardhana, A., AlIzzi, M.A.J., Khalaj, M., dan Hall, M.J.R. 2009. Phylogeography dan recent emergence of the Old World screwworm fly, Chrysomya bezziana, based on mitochondrial dan nuclear gene sequences. Med Vet Entomol, 23 (Suppl. 1), 43-50.

Ribeiro, B. C. C, Sanavria, A., Helena, H., Monteiro, M. S., Oliveira, M. O., dan de Souza, F. S. 2003. An inquiry of cases of myiasis by Dermatobia hominis in dogs (Canis familiaris) of the Northern dan Western zones of Rio de Janeiro city in 2000. Braz. J. Vet. Res. Anim. Sci. 40(1), 144-150.

Ribeiro, B. C. C., Sanavria, A., de Oliveira, M. Q., de Souza, F. S., Rocco, F. S., dan Cardoso, P.G. 2002. Inquiry of cases of myiasis by Dermatobia hominis in dogs of the southern zone of Rio de Janeiro municipality in 2000. Braz. J. Vet. Res. Anim. Sci. 39 (4), 176-180.

Rohela, M., Jamaiah, I., Amir, L., dan Nissapatorn, V. 2006. A case of auricular myasis in Malaysia. J Trop Med Public Health. 37(3), 91-98.

Sankari, L. S., dan Ramakrishnan, K. 2010. Oral myiasis caused by Chrysomya bezziana. J Oral Maxillofacial Surg. 14 (1), 16-18.

Schnur, H. J., Zivotofsky, D., dan Wilamowski, A. 2009. Myiasis in domestic animals in Israel. Vet Parasitol. 161(3-4), 352-355.

Singh, A., dan Singh, D. 2016. A study on the incidence of myiasis among dairy 
animals in theState of Punjab, India. $J$ Agric Vet Sci. 9(1), 30-34.

Sinha, S.K. 2012. Myiasis in domestic animals: new records of calyptrate Diptera. J Parasit Dis., 36(2), 277-279.

Soyelu, O.T., dan Masika, P. J. 2009. Traditional remedies used for the treatment of cattle wounds dan myiasis in Amatola Basin, Eastern Cape Province, South Africa. Onderstepoort J Vet Res, 76 (4), 393-397.

Stevens, J.R. 2003. The evolution of myiasis in blowflies (Calliphoridae). Int $J$ Parasitol. 33 (10), 1105-1113.

Sucilathangam, G., Meenakshisundaram, A., Hariramasubramanian, S., Andanhi, D., Palaniappan, N., dan Anna, T. 2013. External ophthalmomyiasis which was caused by sheep botfly (Oestrus ovis) larva: A report of 10 cases. J Clin Diag Res. 7 (3): 539-542.

Sukarsih, Partoutomo, S., Wijffel, G., dan Willadsen, P. 2000. Vaccination trials in sheep against Chrysomya bezziana larvae using the recombinant peritrophin antigens Cb15, Cb42 dan Cb48. JITV. Spec. Ed.

Sukarsih, Tozer, R.S., dan Knox, M.R. 1989. Collection dan case incidence of the old world screwworm fly, Chrysomya bezziana, in three localities in Indonesia. Penyakit Hewan. 21 (38), 114-117.

Tabouret, G., Jacquiet, P., Scholl, P., dan Dorchies, P. 2001. Oestrus ovis in sheep: relative third-instar populations, risks of infection dan parasitic control. Vet Res. 32(6), 525-531.

Tang, R., Zhang, F., Kone, N., Chen, J.H., Zhu, F., Han, R.C., Lei, C.L., Kenis, M., Huang, L.Q., dan Wang, C.Z. 2016 .Identification dan testing of oviposition attractant chemical compounds for Musca domestica identification and testing of oviposition attractant chemical compounds for Musca domestica. Sci. Rep., 6 (33017), $1-9$.

Traversa, D., dan Otranto, D. 2006. A new approach for the diagnosis of myiasis of animals: The example of horse nasal myiasis. Vet Parasitol. 141(1-2), 186-190.

Umadevi, U., dan Umakanthan, T. 2016. Herbal treatment for myiasis in cattle - a field trial. J Agric Vet Sci. 9 (9), 25-26.

Wardhana, A.H., dan Muharsini, S. 2005. Kasus myasis yang disebabkan oleh Chrysomya bezziana di pulau Jawa. Prosiding Seminar Teknologi Peternakan dan Veteriner Bogor, 12-13 September 2005. 1078-1084

Widhyari, S.D., Wientarsih, I., Mustika, A. A., Wardhana, A. H., Darmakusuma, D., Sutardi, L. N., dan Bintang, M. 2018. Potensi salep ekstrak daun sirih merah terhadap profil eritrogram sebagai terapi pada luka miasis. J Veteriner 19 (1), 30-34.

Wientarsih, I., Mustika, A. A., Wardhana, A. H., Darmakusumah, D., dan Sutardi L. N. 2017. Daun binahong (Danredera cordifolia steenis) sebagai alternatif insektisida terhadap miasis yang disebabkan lalat Chrysomya bezziana. J Veteriner. 18 (1), 121-127.

Yones, D.A., Bakir, H.Y., dan Hameed, D.A. 2014. Human urogenital myiasis caused by psychoda species larvae: report of five cases dan morphological studies. J. $A d v$. Parasitol. 1 (2), 12-20.

Zanzani, S. A., Cozzi, L., Olivieri, E., Gazzonis, A. L., dan Manfredi, M. T. 2016. Oestrus ovis L. (Diptera: Oestridae) induced nasal myiasis in a dog from Northern Italy. Case Reports in Veterinary Medicine 2016. 1(1), 1-4. 